\title{
Training and Development Needs Assessment in a large NIHR Biomedic al Research Centre: A Survey
}

\author{
Karen Bell1, ${ }^{\dagger}$, Syed Ghulam Samar Shah ${ }^{1,2,+, *}$, Loma R. Henderson ${ }^{1,2}$, Vasiliki \\ Kiparoglou ${ }^{1,3}$
}

1NIHR Oxford Biomedic al Research Centre, Oxford University Hospita Is NHS Trust, J ohn Ra dc liffe Hospital, Hea dington, Oxford, OX3 9DU, United Kingdom

2Ra d cliffe Department of Medic ine, Medic al Sciences Division, University of Oxford, J ohn Ra dcliffe Hospital, Headington, Oxford, OX3 9DU, United Kingdom

${ }^{3}$ Nuffield Depa rtment of Primary Health Care Sciences, University of Oxford, Ra dc liffe Prima ry Ca re Building, Ra d c liffe O bservatory Q ua rter, Woodstock Road, Oxford. OX2 6GG, United Kingdom

\section{*Corresponding authors}

Name: Syed G hulam Sa rwar Shah

Email: Sarwar.Shah@ouh.nhs.uk

Twitter: @SarwarShahUK

†J oint Firstauthorships: The a uthors have informed that they agree that both Karen Bell and Syed G hulam Sarwar Sha h completed the intellectual and other work typic al of the first author.

\section{ABSTRACT}

Objective: To assess the training and development needs of researchers and support staff a ffiliated to the NIHR Oxford Biomedical Research Centre (BRC), one of the largest BRCs in England, and to find out about their past experiences of training.

Design: A cross-sectional online questionna ire survey.

Setting and Participants: A convenience sample of clinic ians, nurses, mid wives, allied health professionals, researchers and support staff $(\mathrm{N}=798)$ affilia ted with the NIHR Oxford Biomedical Research Centre.

Primary and secondary outc ome measures: The primary outc ome mea sure was the type of training and the secondary outc ome measures were the duration, location and timing of training.

Results: The response rate was $24 \%$. Of 189 respondents, 114 were women (60\%) and 75 men (40\%). Respondents included research scientists (31\%), medic al doctors and dentists (17\%), nurses and midwives (16\%) and research managers and a dministrators (16\%). Seventy-one percent respondents $(n=134)$ reported attending at least one training activity in the last year and the most wanted training was leadership skills (25\%), followed by research grant and fellowship writing (18\%) and 
medRxiv preprint doi: https://doi.org/10.1101/2021.08.27.21261708; this version posted August 29, 2021. The copyright holder for this preprint (which was not certified by peer review) is the author/funder, who has granted medRxiv a license to display the preprint in perpetuity.

It is made available under a CC-BY 4.0 International license .

statistical analysis (16\%). An ideal length of a training course was half a day (41\%), whole day ( $25 \%)$ and $1-2$ hours (22\%). The most preferred time of the day for training wasmoming (60\%) and aftemoon (22\%) and the favoured delivery style of training was an interactive workshop (52\%), lecture/talk (25\%), online $(9 \%)$ and practical activities (9\%). The main ba miers to attending training courses were the lack of time (n-18\%), work commitments (13\%), and childca re responsibilities (6\%).

Conclusions: Translational resea rchers and supporting a ffilia tes wa nt short, ea sily a c c essible, interac tive training sessions, partic ula rly lea dership training skills and grant and fellowship writing. However, practic al elements a re important too e.g. in a convenient location during the working day. Work commitment is the biggest obstacle in doing training.

Keywords Tra nslational research, Professional tra ining and development, Training needs evaluation, Ba miers to training, Leadership training.

\section{Strengths and limitations of this study:}

- This survey was done to develop and revamp the NIHR Oxford BRC's training programme that met the training and development needs of our researchers and research support staff.

- Leadership skills, resea rch grant and fellowship writing, sta tistical a nalysis were the most wanted training.

- The lack of time, work commitments, and childcare responsibilities were the ma in ba miers to attending training courses.

- Our findings have limited generalisa bility because the study is based on the responses of participants who a re affiliated with only one NIHR BRC; hence, these findings could not be generalised to other NIHR BRCs.

- These findings might inform the training and development programmes in other NIHR BRC s in the country.

\section{INTRODUCTION}

The National Institute for Health Research (NIHR) Biomedic al Research Centres are part of the Govemment's initiative to improve the translation of basic scientific developments into clinic al benefits for patients and to reinforce the position of the UK as a global leader in healthc are related research. ${ }^{1}$ The NIHR Oxford Biomedical Research Centre (BRC) is a partnership that brings together the research expertise of the University of Oxford and the clinic al skills of staff of Oxford University Hospita Is NHS Foundation Trust with the a im of supporting translational research and innovation to improve healthcare for patients. ${ }^{2}$

The NIHR Oxford BRC's overarching strategy foc uses on building capacity with the explic it a im to attract, develop and reta in the best resea rch professionals. ${ }^{1}$ Firstly, by providing opportunities for ta lented healthcare research staff to und ertake their own research through higher degrees, as well as via shorter research fellowships. Secondly, to facilita te the training and engagement in professional development of all of its a ffilia tes including researchers and resea rch support staff.

NIHR reviewed their training program in $2015^{1}$ and found that there was a need to develop innovative approaches to train the translational research workforce of the 
medRxiv preprint doi: https://doi.org/10.1101/2021.08.27.21261708; this version posted August 29, 2021. The copyright holder for this preprint (which was not certified by peer review) is the author/funder, who has granted medRxiv a license to display the preprint in perpetuity.

It is made available under a CC-BY 4.0 International license .

future, and to develop their career pathways as the clinical and translational environment is changing rapidly. Training is vital to mainta in a skilled workforce as healthca re changes with technological advances and emerging disea ses such as COVID-19. ${ }^{3}$ It is also a way for individuals to develop their careers, improving confidence and motivation and ultimately retention. ${ }^{4}$ In addition, training and development is essential for improving patient c are ${ }^{5}$ as well as research and innovation. ${ }^{6,7}$

The NIHR Oxford BRC spends in the region of $₫ 300,000$ a year on training and education for translational researc $h$ staff. This is a bout $1.3 \%$ of its total a nnual budget of $f 23 \mathrm{~m}$. On average, a bout 70 researchers a year benefit from tra ining support which includesproviding training bursaries, fellowships, and bespoke courses including leadership, health economic sand grant writing skills. The NIHR Oxford BRC works c ollaboratively with other orga nisations including the Clinic al Research Network, the Oxford Health BRC and University of Oxford who also provide a range of free training opportunities for their students and staff.

Following reorganisation within the NIHR Oxford BRC a dedicated Training and Education Manager was a ppointed to a new role in 2019. In order to plan an effective training programme, we sought the views of researchers and support staff within and affiliated to the NIHR Oxford BRC about their training needs. This was imperative because according to the 2019 Researcher Development Concordat ${ }^{8}$, researchers must be equipped and supported to be adaptable and flexible in an increa singly diverse global research environment and employment market. This Principle recognises the importance of continuous professional and career development, particularly as researchers pursue a wide range of careers ${ }^{8}$. Most c linical practitioners receive regular professional training such as good clinical practice and obtaining ethical approval, but not leadership training and research skills, which are associated with progression in rank, leadership position and research public ation. ${ }^{9}$

The objective of this study was to assess the training and development needs of researchers and support staff a ffilia ted to the NIHR Oxford BRC and to find out about their past experiences of tra ining.

\section{METHODS}

\section{Study Design}

This was a cross sectional questionna ire survey study.

\section{Study setting}

The NIHR Oxford BRC is based at the Oxford University Hospitals NHS Foundation Trust and run in partnership with the University of Oxford. ${ }^{2}$ Founded in 2007, it is one of five centres funded by the NIHR and has received over f260m since 2007 to support translational research. The NIHR Oxford BRC is divided into 20 research themes with over 500 research and research support staff paid for by the NIHR Oxford BRC..$^{2}$ In addition to BRC staff, we also sent the questionnaire to people who are involved with translational research but not paid directly by the BRC, such as NHS research nurses. 
medRxiv preprint doi: https://doi.org/10.1101/2021.08.27.21261708; this version posted August 29, 2021. The copyright holder for this preprint (which was not certified by peer review) is the author/funder, who has granted medRxiv a license to display the preprint in perpetuity.

It is made available under a CC-BY 4.0 International license.

\section{Study population}

The study population included anyone involved in translational research and affilia ted to the NIHR Oxford BRC. This included medical doctors, nurses, mid wives, allied health professionals, clinic al scientists, statisticians, software engineers, a dmin staff and clinical trial managers but was not limited to staff paid directly by the NIHR Oxford BRC.

\section{Development of the survey questionnaire}

The survey questionnaire was developed in house and comprised 10 questions with a mix of multiple-choice questions and free text answers (Appendix 1. NIHR Oxford BRC Training and Development Questionnaire). These questions asked for partic ipants' gender and role, training type, time, duration, loc ation and delivery style, training attended in the last year, most wanted training, and ba miers to attending training. Participants were also given an open-ended choice to comment on the training received in the past. The questionnaire was intended to be quick and easy to complete while capturing the information needed to develop and revamp the NIHR Oxford BRC's training programme that met the training and development needs of our researchers and research support staff. The questionnaire was developed using the J ISC online survey software (J ISC $®)$ - an online survey tool designed for academic research, education and public sector organisations. ${ }^{10}$ The questionnaire waspiloted with five members of the core administration team of the BRC.

\section{Administration of the survey}

Using the J ISC ${ }^{\circledR}$ online surveys ${ }^{10}$, the training survey was sent via personalised emails to 798 people associated/affilia ted with the NIHR Oxford BRC in October 2019. They were given two months to respond, with two reminders. We received 189 responses (24\%) by 31 December 2019. Responses were collated using the J ISC software. With the J ISC ® online survey, data was secure and strict information security standards were followed (ISO27001)11 in compliance with the General Data Protection Regulations (GDPR). ${ }^{12}$

\section{Data analysis}

Online data from J ISC $®$ was analysed and tablesand graphswere produced for preliminary analysis. Data were also downloaded into SPSS13 and Microsoft Excel spread sheet formats. Data were analysed for frequencies and desc riptive sta tistics. We did not impute missing values, which were very low and we did not run any inferential statistic al a na lyses. We did not conduct a ny sensitivity a nalysis.

\section{Patientand public involvement}

Neither patients nor the public were involved in this study because it was a survey about the professional tra ining and development needs of translational health researchers and support staff affilia ted with our BRC.

\section{Reporting c hec klist}

We report this study according to the Consensus-Based Checklist for Reporting of Survey Studies (CROSS) ${ }^{14}$. 


\section{RESULTS}

The response rate was $24 \%$ (189 responded of 798 invited). Of the 189 respondents, 114 were women (60\%) and 75 were men (40\%) and included research scientists, medical doctors and dentists, nurses and midwives, research ma na gers and a dministrators and others (Table $\mathbf{1}$ ). The partic ipants were from all 20 research themes plus the NIHR Oxford BRC mana gement team (Table 1).

\section{Training received in the lastyear}

Sixty percent of respondents $(n=113)$ reported receiving at least one tra ining course in the last year (Table $\mathbf{1}$ ). The most common training received included professional qualific ations such as Master's degree $(n=23)$, followed by good clinical practice $(n=19)$, leadership $(n=14)$, and bioinformatic s and statistic $s(n=12)$. However, a bout $40 \%$ respondents $(n=76)$ reported not receiving any training in the last year.

Table 1 Respondents' role and training received and needed.

\begin{tabular}{|c|c|c|}
\hline & Count & $\%$ \\
\hline \multicolumn{3}{|l|}{ Participants' role ( $\mathbf{N}=\mathbf{1 8 9})$} \\
\hline Research scientist & 59 & 31.2 \\
\hline Medical doctor/ dentist & 32 & 16.9 \\
\hline Research nurse/midwife & 30 & 15.9 \\
\hline Administrator/manager & 30 & 15.9 \\
\hline Other (clinical sc ientists, pha rma cists, statisticians) & 24 & 12.7 \\
\hline Research Allied Health Professionals & 14 & 7.4 \\
\hline \multicolumn{3}{|l|}{ Training received in the last year* } \\
\hline Professional qualific a tions including masters' degrees & 23 & 12.2 \\
\hline Good Clinic al Practice (GCP) & 19 & 10.0 \\
\hline Lea dership & 14 & 7.4 \\
\hline Bio informatic sand statistics & 12 & 6.3 \\
\hline Clinical trials & 8 & 4.2 \\
\hline Good Research Practice (GRP) & 8 & 4.2 \\
\hline IT modules & 8 & 4.2 \\
\hline Conferences and seminars & 7 & 3.7 \\
\hline Ethic $s$ & 4 & 2.1 \\
\hline General Data Protection Regulations (GDPR) & 4 & 2.1 \\
\hline Grants (writing and applying) & 4 & 2.1 \\
\hline Informed consent & 4 & 2.1 \\
\hline Communications & 3 & 1.6 \\
\hline Data management & 3 & 1.6 \\
\hline Public a tions & 3 & 1.6 \\
\hline Qualita tive interviewing & 3 & 1.6 \\
\hline Anti-bullying & 1 & 0.5 \\
\hline Equa lity \& diversity & 1 & 0.5 \\
\hline Experimental design & 1 & 0.5 \\
\hline Health Ec onomics & 1 & 0.5 \\
\hline Patient and Public Involvement (PPI) in Research & 1 & 0.5 \\
\hline Project management & 1 & 0.5 \\
\hline
\end{tabular}




\begin{tabular}{|c|c|c|}
\hline Teaching & 1 & 0.5 \\
\hline None & 76 & 40.2 \\
\hline \multicolumn{3}{|l|}{ Training found most valuable $(n=65)$} \\
\hline Lea dership & 11 & 16.9 \\
\hline Sta tistic s & 8 & 12.3 \\
\hline Good Clinic al Practice (GCP) & 5 & 7.7 \\
\hline Conferences & 5 & 7.7 \\
\hline Information Technology (IT) & 5 & 7.7 \\
\hline Lab/research skills & 5 & 7.7 \\
\hline Clinic al trials & 4 & 6.2 \\
\hline Grants & 4 & 6.2 \\
\hline Professional qualific ations & 3 & 4.6 \\
\hline Ethic s & 3 & 4.6 \\
\hline Public a tions & 3 & 4.6 \\
\hline Networking & 2 & 3.1 \\
\hline Epidemiology & 1 & 1.5 \\
\hline Good Research Practice (GRP) & 1 & 1.5 \\
\hline Clinic al skills & 1 & 1.5 \\
\hline Qualita tive interviews & 1 & 1.5 \\
\hline Informed Consent & 1 & 1.5 \\
\hline Presentations & 1 & 1.5 \\
\hline Teaching & 1 & 1.5 \\
\hline \multicolumn{3}{|c|}{$\begin{array}{l}\text { Training area most important to respondent's development } \\
\text { and training needs }(n=178)\end{array}$} \\
\hline Lea dership skills & 44 & 24.7 \\
\hline Grant/fellowship writing & 32 & 18.0 \\
\hline Sta tistic al a na lysis & 28 & 15.7 \\
\hline Clinic al skills (PPI, GCP, informed consent) & 16 & 9.0 \\
\hline Designing and conducting clinical trials & 16 & 9.0 \\
\hline Other (Project management, programming and IT) & 15 & 8.4 \\
\hline Research skills (G RP, lab skills) & 13 & 7.3 \\
\hline Academic writing & 9 & 5.1 \\
\hline Presentation skills & 5 & 2.8 \\
\hline
\end{tabular}

\section{Most important training area for personal development and training}

The respondents reported different a reas of training for personal development and training and the most wanted training wasleadership skills (25\%), research grant and fellowship writing (18\%) and statistical analysis (16\%) (Table 1).

\section{Length and time of training}

For respondents, the ideal length of a tra ining course was half a day (41\%), whole day (25\%) and $1-2$ hours (22\%) (Figure 1). The most preferred time of the day for training was moming (60\%) and aftemoon (22\%) (Figure 1). 


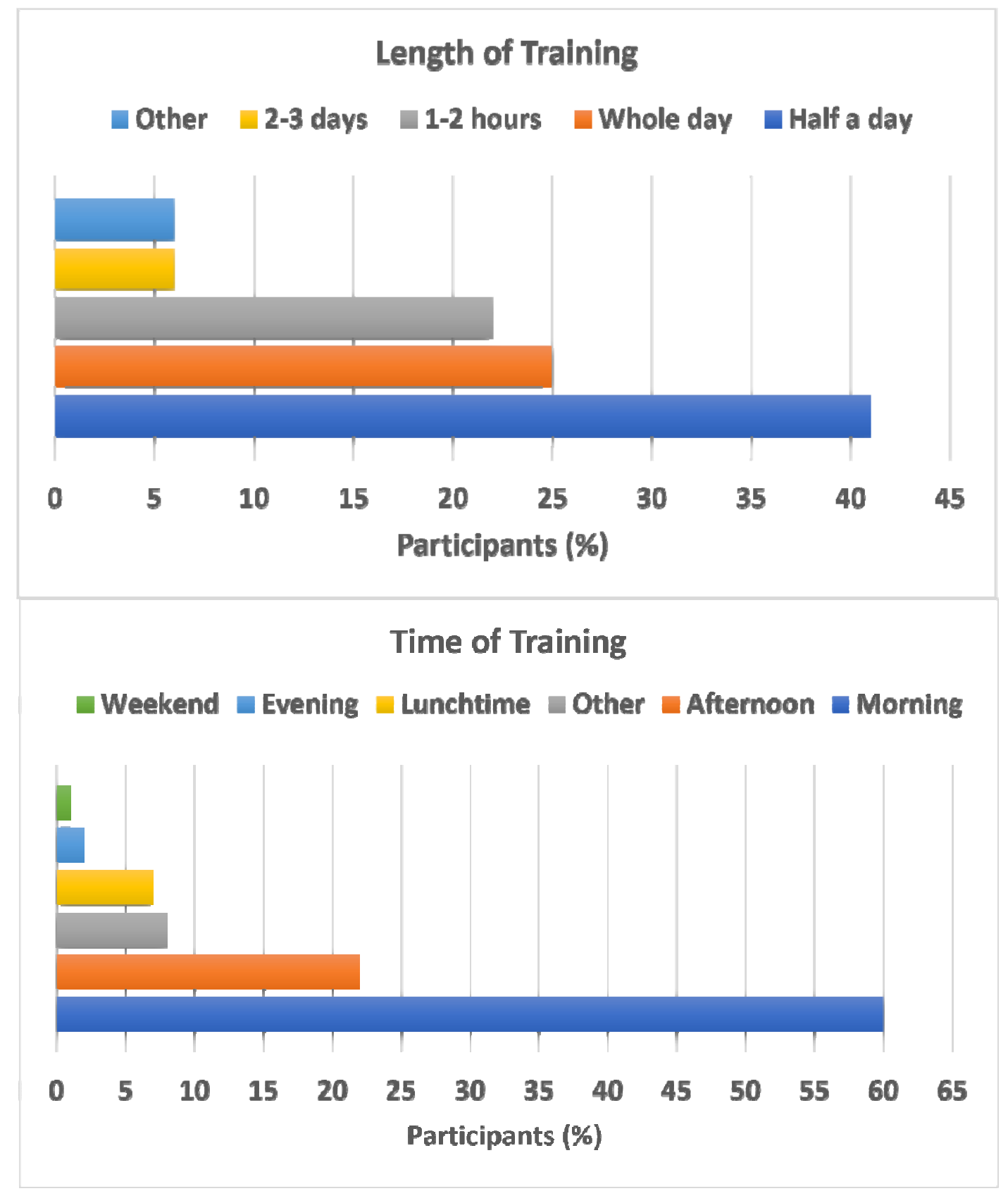

Figure 1. Ideal length and time of training.

\section{Training delivery}

For the delivery of training, the participants suggested different delivery styles including interac tive workshops (52\%), lec tures/ talks (25\%), online tra ining (9\%) and prac tic al ac tivities (9\%) (Figure 2). 
medRxiv preprint doi: https://doi.org/10.1101/2021.08.27.21261708; this version posted August 29, 2021. The copyright holder for this preprint (which was not certified by peer review) is the author/funder, who has granted medRxiv a license to display the preprint in perpetuity.

It is made available under a CC-BY 4.0 International license .

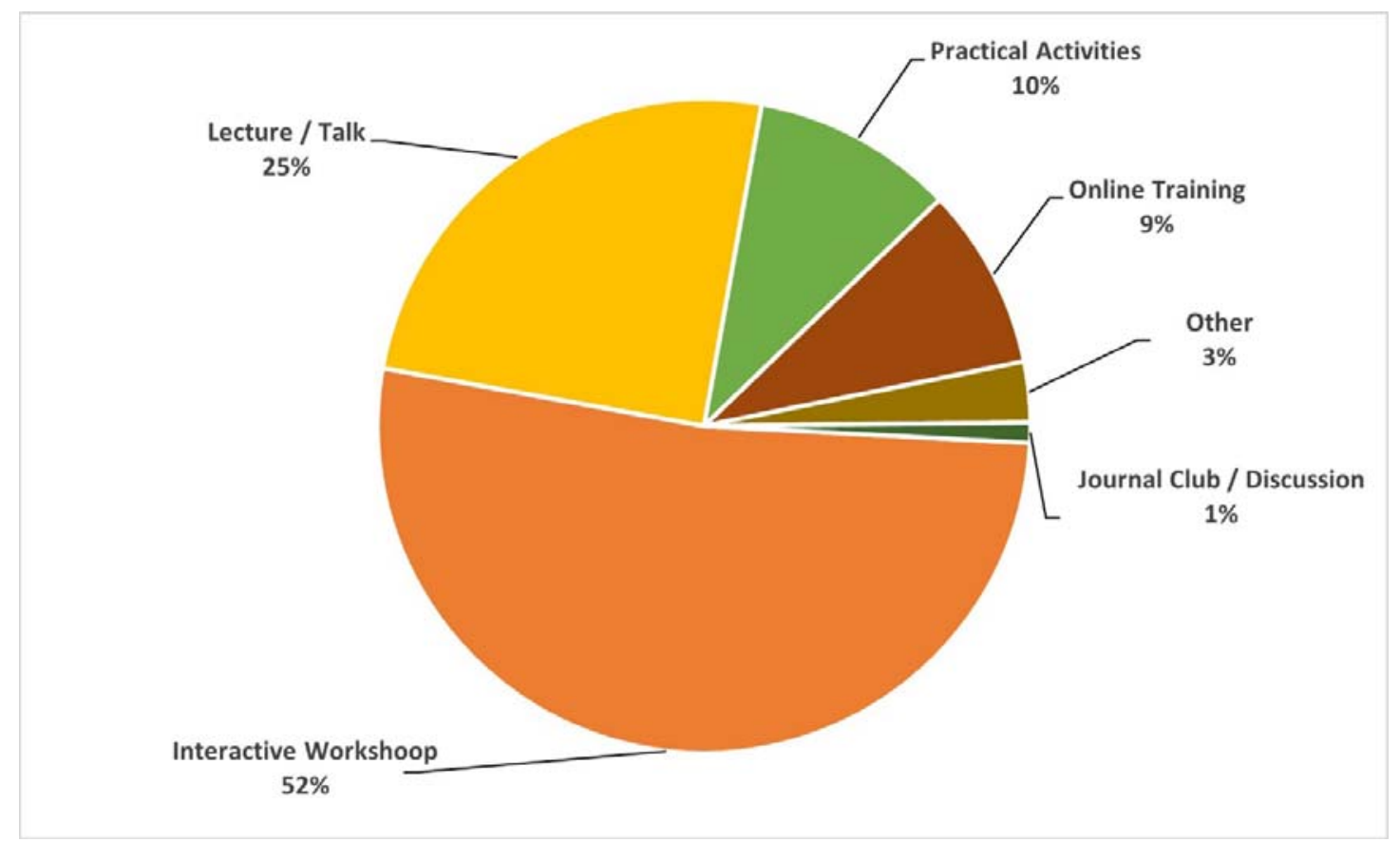

Figure 2 Training delivery styles suggested by participants.

\section{Bamiers in attending Training}

For $58 \%$ respondents $(n=109)$ there were no ba riers while the remaining partic ipants $(42 \%, n=80)$ reported a range of bamiers that prevented them from attending training courses. The most common issues stopping from attending tra ining courses were the lack of time $(18 \%, n=34)$, work commitments $(13 \%, n=25)$, a nd child care responsibilities $(6 \%, n=11)$. Other less common ba miers to training were cost $(2 \%, n=3)$, suffic ient notice $(1 \%, n=2)$, permission $(1 \%, n=2)$, parking $(n=1,0.5 \%)$, location $(n=1$, $0.5 \%)$ and relevance $(n=1,0.5 \%)$.

\section{Open ended comments about training and development}

Although a large number of respondents did not do a ny tra ining $(n=76,40 \%)$, those who did training, found it very useful. Box 1 provides selected comments showing the value and applic ation of training in work, training tailored to the roles, research specific training, and training on clinic al and epidemiological skills.

\section{Training applicable at work}

The Biomedical Data science training program was an incredible course, I learned a lot and have been able to apply it to my own data. (Respondent \# 34,Female, Research Scientist)

Training tailored to the role 
medRxiv preprint doi: https://doi.org/10.1101/2021.08.27.21261708; this version posted August 29, 2021. The copyright holder for this preprint (which was not certified by peer review) is the author/funder, who has granted medRxiv a license to display the preprint in perpetuity.

It is made available under a CC-BY 4.0 International license .

The EMBO course: 30 hours of high quality leadership training tailored specifically to my role as a new Pl. (Respondent \# 35, Male, Research Scientist)

Leadership training SBS access to wide network of International leaders and techniques to apply to the BRC and make a difference. (Respondent \# 43, Female, Manger)

Information Governance at HTA as these are key aspects of my role. (Respondent \# 150, Female, research nurse/midwife)

\section{Research specific training}

Clinical Trial (training).... allowed me to run my study more carefully (Respondent \# 67, Male, medical doctor/dentist)

Publication schools - excellent and engaging faculty, gained a lot of knowledge about publishing process and the university regulations. (Respondent \# 47, Female, Medical doctor/ Dentist)

HRA approvals as it was short so able to go in work time and relevant to job. (Respondent \# 129, Female, Research nurse/Midwife)

GCP update as relevant and practical and opportunity to meet other research staff. (Respondent \# 134, Female, Research nurse/Midwife)

\section{Clinical and epidemiological skills training}

Epidemiological assessment of vaccines provided me with knowledge applicable to my current post. Tropical Nursing provided me with a wider knowledge of the diseases we are looking vaccines for. (Respondent \# 78, Male, Research nurse / Midwife)

The vaccinology courses gave me more knowledge and understanding to work at a higher standard that was required, and the other training was helpful for career progressing. (Respondent \# 185, Female, Administrator / manger)

Communications course - Extremely useful for having difficult conversations. (Respondent \# 1 12, Female, medical doctor/dentist)

\section{Box 1. Open ended comments by respondents.}

\section{DISCUSSION}

Nearly 800 people were personally sent the questionnaire of whom $54 \%$ were female and $46 \%$ male. The response rate was $24 \%$, with six out of ten respondents being women ( $27 \%$ of cohort) and $40 \%$ men ( $20 \%$ of the cohort). The la rgest professional group to respond were research scientists at just over $30 \%$. 
medRxiv preprint doi: https://doi.org/10.1101/2021.08.27.21261708; this version posted August 29, 2021. The copyright holder for this preprint (which was not certified by peer review) is the author/funder, who has granted medRxiv a license to display the preprint in perpetuity.

It is made available under a CC-BY 4.0 International license .

Although, the majority of respondents reported receiving training in the past year, the usefulness of the training was mixed. However, training that was directly linked to professional and career development was well received because it has implications not only for developing competency, rec ruitment and retention but also improving healthca re delivery. ${ }^{4}$ Tra ining in lea dership skills and research and grant writing were highlighted as possible future training opportunities because these skills are associated with progression in rank, lea dership position and research public ation. ${ }^{9}$ In a ddition, tra ining in lea dership and management helps in increasing personal effectiveness and promoting a positive attitude to professional development. ${ }^{8}$ Most notably, the need forleadership skills training was more in women compared to men respondents ( 7 women vs. 3 men). These findingsindic ate a gap in leadership in women in translational research settings. ${ }^{15,16}$ Lea dership is a marker of a chievement in biomedic al research organisa tions. ${ }^{17}$ Therefore, gender equity in lea dership is essential, 16,17 and the gender gap in lea dership could be reduced by providing training in leadership skills.

Participants were also a sked about the location, time and delivery of tra ining courses. The most popular time of training delivery was mornings, training delivery style was interactive workshops and training location was near to where they work, which provides support to the recommendations made for the training of health and care workforce. ${ }^{18}$ Our findings show that busy people, like clinicia ns and nurses, need to be able to access training easily, it has to be close by their workplace and to fit in with crowded work schedules. ${ }^{19}$

A range of bamiers to attending training were reported and top three barriers were the lack of time, work load and commitments and child care responsibilities. ${ }^{20} \mathrm{About}$ half of nurses and medical doc tors found time and work commitments a major ba mier to training compared to a quarter of administrators, managers and AHPs and $15 \%$ of resea rch scientists. Transportation and Parking, especia lly parking for people with disabilities, is a big issue in Oxford, so not having to travel is a bonus. These findings suggest that professional training must be inclusive and should take in to account the participants' access, location, timing, physical limitations and family commitment especially childcare.

\section{Training gap}

We also asked people what tra ining they had already received and what they found useful. Almost a quarter of the respondents had received no training at all in the previous year. For those who had, one of the main benefits stated was networking with other research staff. While professional training courses such as good clinical practice and informed consent continue to be mandatory there is definitely an appetite for personal development.

Interestingly of the 44 people who cited leadership as the training area most important to their development and tra ining needs, 59\% were women. However, only $12(27 \%)$ were clinic al staff. There have been many studies on the importance of good medical leadership training. ${ }^{21}$ There have been other studies that show that continuing medic al educ ation has the capacity to deliver high quality healthc are and to address many of the challenges in the health care environment. ${ }^{22}$ Our study shows that there is an unfulfilled need for a range of training opportunities, partic ularly lea dership tra ining, for all translational researchers. The results of the survey will now help us to develop training as an integral part of career development pathways for our staff that meet their needs for professional and careeradvancement. 
medRxiv preprint doi: https://doi.org/10.1101/2021.08.27.21261708; this version posted August 29, 2021. The copyright holder for this preprint (which was not certified by peer review) is the author/funder, who has granted medRxiv a license to display the preprint in perpetuity.

It is made available under a CC-BY 4.0 International license.

\section{CONCLUSIONS}

Most researchers and research support staff in translational resea rch settings like the NIHR BRC s want short training sessions, in a convenient loc ation during the working day, preferably in the momings. The tra ining provided needs to be easily accessible, interactive and relevant. The most important a reas for tra ining include leadership skills, grant and fellowship writing and statistic al a pplic a tions. The biggest obstacle preventing translational researchers especially clinic ia ns and nurses from doing training is work commitment.

\section{Acknowledgements}

The authors wish to thank all partic ipants for taking time to complete the survey.

\section{Ethic sstatement}

This study was an evaluation of the training and development service. We used the Health Research Authority (HRA) decision tool whether our study required NHS ethics a pproval. The HRA tool results suggested that our study would not be considered Research; hence, NHS ethic s a pproval was not required and obtained. In a ddition, our retrospective applic ation for ethic s approval was reviewed by the Offic er of the Oxford University Medical Sc iences Interdivisional Resea rch Ethic s Committee, with reference to formally approved process and determined that the study would be classified as evaluation, rather than research, therefore does not require ethic al review (CUREC Applic ation: R77595/RE001, date August 26, 2021).

\section{Funding}

This study was funded/supported by the National Institute for Health Research (NIHR) Oxford Biomedical Research Centre (Research Grant No. IS-BRC-1215-20008). The views expressed are those of the author(s) and not necessarily those of the NHS, the NIHR or the Department of Health. The funders had no role in study design, a nalysis and interpretation of this study.

\section{Data availability statement}

All data are reported in this article; hence, no additional data are available.

\section{Conflict of interest}

K. Bell is Training and Education Project Manager, S. G. S. Shah is Senior Research Fellow, L R. Henderson is C linic al Research Manager and V. Kparoglou is chief Operating Offic er at the National Institute for Health Research (NIHR) Oxford Biomedic al Research Centre, Oxford University Hospita Is NHS Trust, J ohn Rad cliffe Hospital, Oxford, England, United King dom.

\section{Author's contributions}

KB devised and caried out the survey, did the initial a nalysis and wrote some parts of the manuscript. SGSS a nalysed the data, created visualisationsand led drafting, 
medRxiv preprint doi: https://doi.org/10.1101/2021.08.27.21261708; this version posted August 29, 2021. The copyright holder for this preprint (which was not certified by peer review) is the author/funder, who has granted medRxiv a license to display the preprint in perpetuity.

It is made available under a CC-BY 4.0 International license .

revising and finalising of the manusc ript. LRH reviewed and contributed to editing and redrafting the manuscript. VK reviewed the manuscript for critical intellectual input and acquired funds for open access public a tion of this paper.

\section{REFERENCES}

1. National Institute for Health Research (NIHR). Ten Years On: Adapting and Evolving to New Challenges in Developing Tomorrow's Health Research Leaders. NIHR Trainees Coordination Centre; 2017:1-22.

https:// www.nihr.a c.uk/a bout-us/ our-contribution-to-rese arc h/ equa lity-diversityand-inclusion.htm

2. NIHR Oxford Biomedical Research Centre. About the NIHR Oxford Biomedical Research Centre. Published 2020. Accessed September 4, 2020.

https://oxfordbrc.nihr.ac.uk/about-us-intro/

3. Shah SGS, Farrow A. A commentary on "World Health Organization decla res global emergency: A review of the 2019 novel Coronavinus (COVID-19)." Int J Surg. 2020;76:128-129. doi:10.1016/j.ijsu.2020.03.001

4. Price $S$, Reic hert $C$. The Importance of Continuing Professional Development to Career Satisfa ction and Patient C a re: Meeting the Needs of Novice to Mid- to La te-Career Nurses throughout Their Career Span. Adm Sci. 2017;7(2):17. doi:10.3390/admsci7020017

5. The National Improvement and Lea dership Development Board. Developing People - Improving Care: A National Framework for Action on Improvement and Leadership Development in NHS-Funded Services. NHS Improvement; 2016. https:// improvement.nhs.uk/ documents/542/Developing_PeopleImproving_Care-010216.pdf

6. Royal College of Nursing. Knowledge and Innovation Action Planfor 2014-2018.; 2014. Accessed February 18, 2021. https://www.rcn.org.uk/ professionaldevelopment/ research-and-innovation/knowledge-and-innovation-action-plan

7. Budge EJ, Maria Tsoti S, J a mes Howgate D, Siva kumar S, J a lali M. Collective intelligence for translational medic ine: Crowdsourc ing insights and innovation from an interd isc iplina ry biomedical research community. Ann Med. 2015;47(7):570-575. doi:10.3109/07853890.2015.1091945

8. Vita e. The Concordat to Support the Career Development of Researchers. Careers Research and Advisory Centre (CRAC) Limited; 2019. Acc essed March 10, 2021. https:// www.vita e.ac .uk/policy/concordat/full

9. Straus SE, Soobiah C, Levinson W. The Impact of Lea dership Training Programs on Physicians in Academic Medical Centers: A Systematic Review. Acad Med. 2013;88(5):710-723. doi:10.1097/ACM .0b013e31828af493

10. J isc. Online Surveys.; 2020. https:// www.onlinesurveys.ac.uk/

11. Intemational Organization for Standa rdization. ISO/IEC 27001:2013 Information technology - Security tec hniques - Informa tion security mana gement systems 
medRxiv preprint doi: https://doi.org/10.1101/2021.08.27.21261708; this version posted August 29, 2021. The copyright holder for this preprint (which was not certified by peer review) is the author/funder, who has granted medRxiv a license to display the preprint in perpetuity.

It is made available under a CC-BY 4.0 International license .

— Requirements. Published online 2013.

https:// www.iso.org/standard/54534.html

12. European Union. General Data Protection Regulation (GDPR).; 2016.

https://gdpr-info.eu/

13. IBM Corp. IBM SPSS Statistics for Windows, Version 23.0. IBM Corp.; 2015.

14. Sha ma A, Minh Duc NT, Luu Lam Thang T, et al. A C onsensus-Based Checklist for Reporting of Survey Studies (CROSS). J Gen Intern Med. Published online April 22, 2021. doi:10.1007/s11606-021-06737-1

15. Magliano DJ, Macefield VG, Ellis TM, Calkin AC. Addressing Gender Equity in Senior Leadership Roles in Translational Science. ACS Pharmacol Transl Sci. 2020;3(4):773-779. doi:10.1021/ac sptsci.0c 00056

16. Ovseiko PV, Taylor M, Gilligan RE, et al. Effect of Athena SWAN funding incentives on women's research lea dership. BMJ. 2020;371:m3975.

doi:10.1136/bmj.m3975

17. Henderson LR, Shah SG S, Ovseiko PV, et al. Markers of ac hievement for assessing and monitoring gender equity in a UK National Institute for Health Research Biomedic al Research Centre: A two-factormodel. PLOS ONE. 2020;15(10):e0239589. doi:10.1371/joumal.pone.0239589

18. Beech J, Bottery S, Charlesworth A, et al. Closing the Gap. Key Areas for Action on the Health and Care Workforce. The Health Foundation, The King's Fund, and Nuffield Trust; 2019. https:// www.kingsfund.org.uk/ sites/default/ files/201903/closing-the-gap-health-c a re-workforce-full-report.pdf

19. Sarre S, Maben J, Aldus C, et al. The challenges of training, support and assessment of healthcare support workers: A qua lita tive study of experiences in three English ac ute hospita ls. Int J Nurs Stud. 2018;79:145-153. doi:10.1016/j.jjnurstu.2017.11.010

20. Ilvig PM, Bredahl TVG, J ustesen J B, et al. Attendance ba miers experienced by female health care workers voluntarily partic ipating in a multi-component health promotion programme at the workplace. BMC Pub H. 2018;18(1):1340. doi:10.1186/s12889-018-6254-3

21. Wa rren OJ , Camall R. Medical lea dership: why it's important, what is required, and how we develop it. Postgrad Med J. 2011;87(1023):27.

doi:10.1136/pgmj.2009.093807

22. McMahon GT. The Leadership Case for Investing in Continuing Professional Development. Acad Med. 2017;92(8):1075-1077.

doi:10.1097/ACM.0000000000001619 


\section{Appendix 1. NIHR Oxford BRC Training and Development Questionnaire}

\begin{tabular}{|c|c|c|}
\hline \multicolumn{3}{|c|}{$\begin{array}{l}\text { The NIHR Oxford Biomedical Research Centre (BRC) want to support the } \\
\text { BRC researchers through a range of education and training } \\
\text { opportunities. To help us provide the best service possible, plea se could } \\
\text { you spare a few minutes to compete the questionnaire below? }\end{array}$} \\
\hline & & $\begin{array}{l}\text { Please } \\
\text { tick }\end{array}$ \\
\hline \multicolumn{3}{|c|}{ Q1. Whic h BRC theme do you work in? } \\
\hline . & Genomics & \\
\hline . & Haematology & \\
\hline - & Cancer & \\
\hline - & Respiratory & \\
\hline - & Gastroenterology & \\
\hline - & Vaccines & \\
\hline - & Microbiology & \\
\hline - & Neurology & \\
\hline . & Obesity & \\
\hline - & Stroke & \\
\hline - & Cardiovascular & \\
\hline - & Diabetes & \\
\hline - & Multimorbidity & \\
\hline - & Digital Health & \\
\hline - & Musc uloskeletal & \\
\hline - & Surgery & \\
\hline - & Imaging & \\
\hline - & Moleculardiagnostics & \\
\hline - & Partnerships for Health, Wealth \& Innova tion & \\
\hline . & Informatics & \\
\hline & Other & \\
\hline \multicolumn{3}{|c|}{ If you selected Other, please specify: } \\
\hline \multicolumn{3}{|c|}{ Q2. How would you describe your role? } \\
\hline - & Research Nurse/Midwife & \\
\hline - & Research AHP & \\
\hline - & Research Scientist & \\
\hline - & Medical Doc tor/Dentist & \\
\hline • & Administra tor/ Manager & \\
\hline - & Other & \\
\hline & selected Other, please specify: & \\
\hline
\end{tabular}




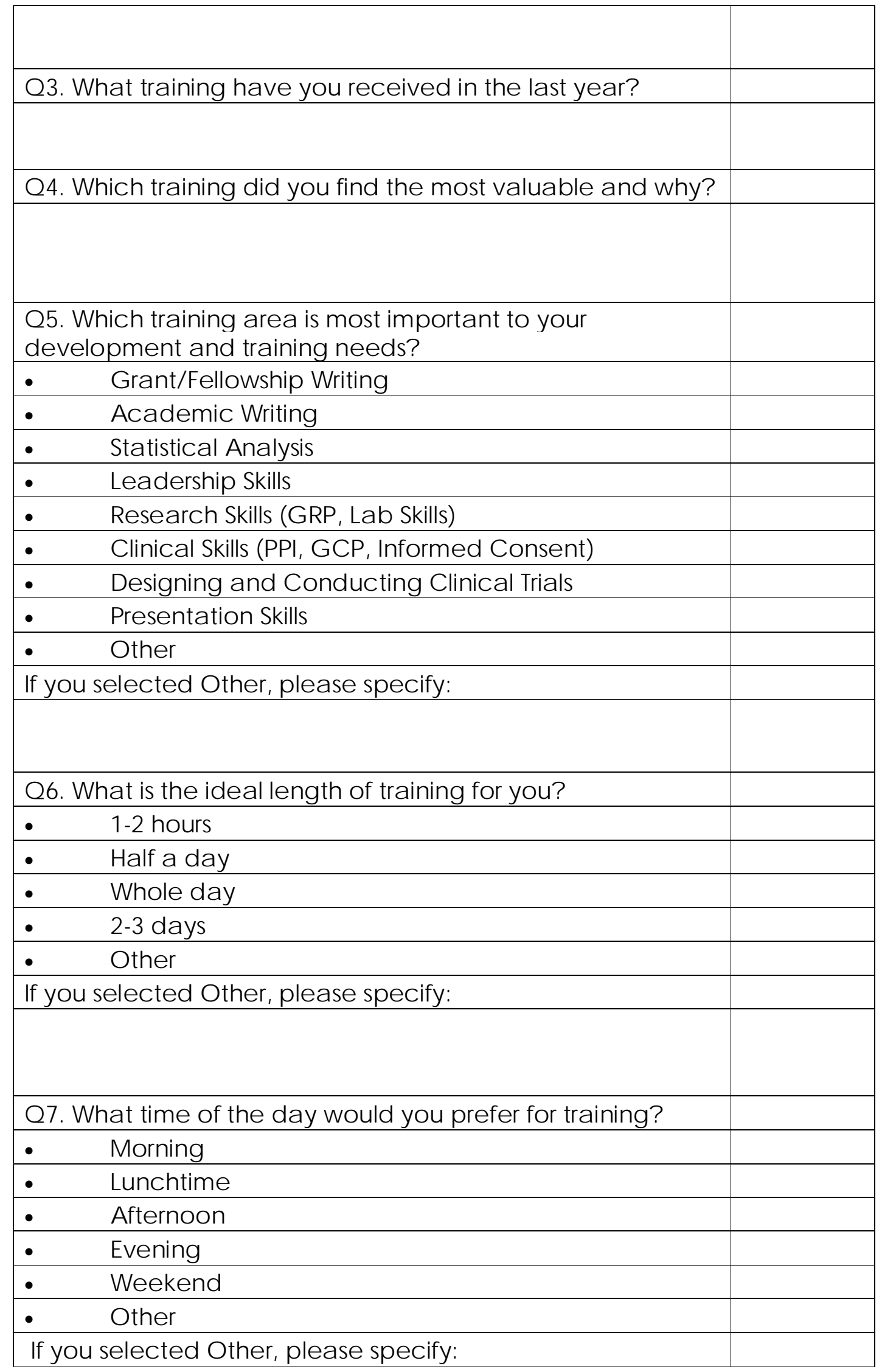




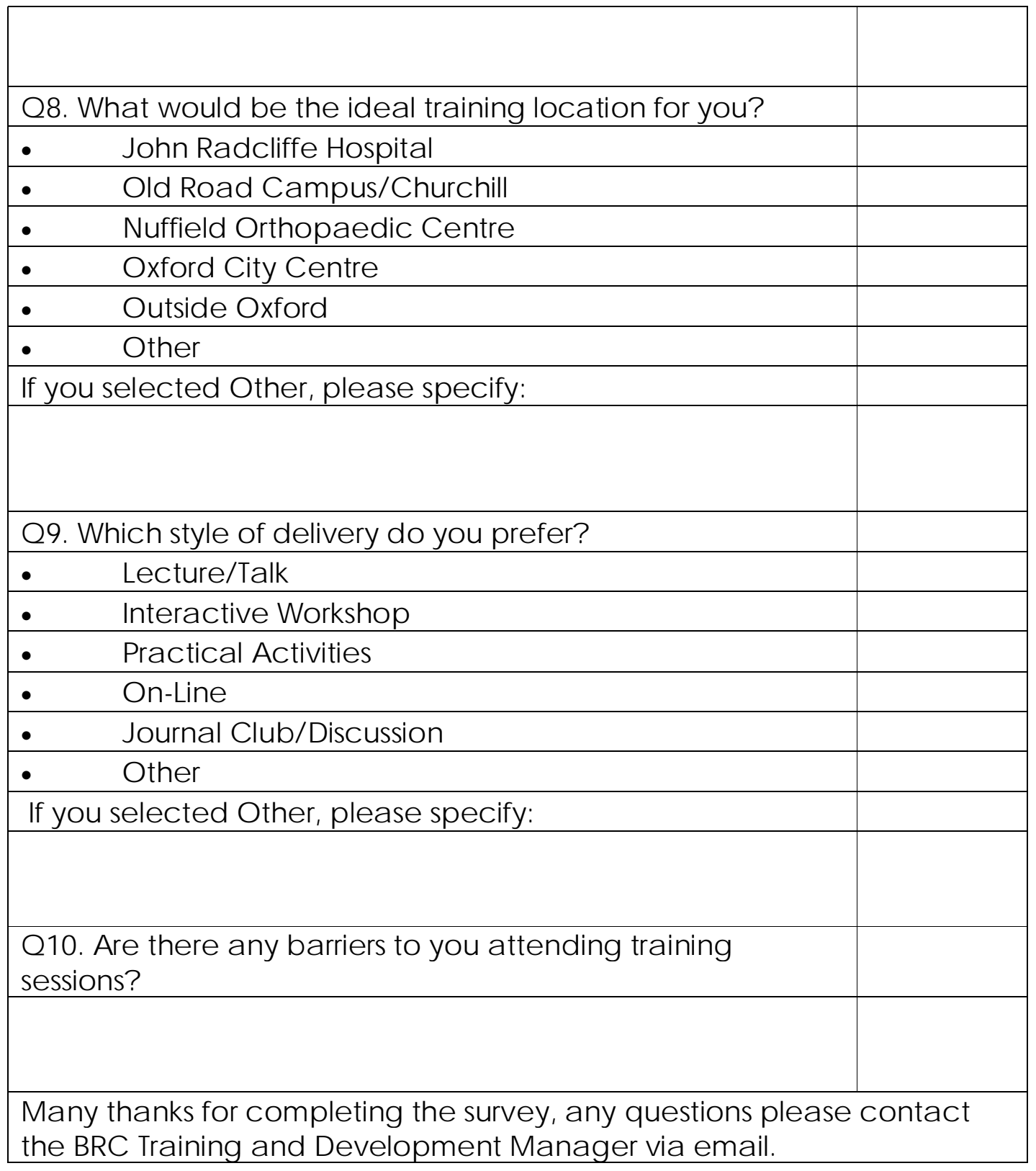

